\title{
Geophysical Characterization of Abandoned Dumpsite Soil Properties for Pre- Foundation Delineation at Bowen University Campus, Iwo, Nigeria
}

\section{1,3AJANI, OO; ${ }^{2}$ ADETOYINBO AA; ${ }^{* 1,3}$ ADENIJI, AA; ${ }^{1,3}$ OMOLIKI, AJ}

\author{
${ }^{I}$ Department of Physics and Solar Energy, Bowen University, Iwo, Nigeria \\ ${ }^{2}$ Department of Physics, University of Ibadan, Nigeria \\ ${ }^{3}$ Solar Energy Research and Application Centre, Bowen University, Iwo, Nigeria \\ *Corresponding Author Email: adetunji.adeniji@bowenuniversity.edu.ng
}

\begin{abstract}
Geophysical investigation and microstudy of soil properties were carried out within Bowen University, for the characterization of the subsurface pattern in the area using vertical electrical sounding (VES) survey and evaluation of soil properties with a view to mapping subsurface geological features, such as weak and competent zones and to determine the overburden thickness of the area for pre-foundation studies for a proposed high-rise building. Four (4) VES was carried out in the study area employing schlumberger electrode configuration. The data collected were used to curve match and the results used for subsequent interpretation to reveal the depth, thickness and resistivity of the study area. In addition, soil samples were collected from three (3) selected points located at the entrance, centre and the end of the study area at about a depth $0-60 \mathrm{~cm}$. Consequently, the VES results were presented as resist graph, which revealed the range of values for the depth $(1.3-24.5)$, thickness $(1.3-15.4 \mathrm{~m})$ and resistivity $(357.4-6311.6 \mathrm{ohms})$, which was later used to generated the geoelectric maps of the study area. It was also observed that the result of the soil properties revealed that all the samples taken from the study area have low bulk density $\left(1.41 \mathrm{~g} / \mathrm{cm}^{3}, 1.26 \mathrm{~g} / \mathrm{cm}^{3}, 1.36 \mathrm{~g} / \mathrm{cm}^{3}\right)$, high particle density $\left(2.81 \mathrm{~g} / \mathrm{cm}^{3}, 2.94 \mathrm{~g} / \mathrm{cm}^{3}, 3.16 \mathrm{~g} / \mathrm{cm}^{3}\right)$, and high porosity $(49.64 \%, 57.22 \%, 57.03 \%)$. In conclusion, it was observed that erection of high-rise building is not advisable within the study area since the results showed that the overburden (depth to basement) is generally thick mostly greater than $15 \mathrm{~m}$. Also revealed from the microstudy of soil properties is that foundation stability should be properly managed, since a porous soil does not accommodate engineering activities except when an artificial basement is put in place.
\end{abstract}

\section{DOI: https://dx.doi.org/10.4314/jasem.v23i1.19}

Copyright: Copyright (c) 2019 Ajani et al. This is an open access article distributed under the Creative Commons Attribution License (CCL), which permits unrestricted use, distribution, and reproduction in any medium, provided the original work is properly cited.

Dates: Received: 17 October 2018; Revised: 05 January 2019; Accepted 17 January 2019

Keywords: Geophysical Investigation, Soil Analysis, Foundation Studies, Subsurface Competency

The incessant incidence of structural failure is becoming alarming in Nigeria and this failure can be attributed to a number of factors such as inadequate information about the soil, subsurface geological material, poor foundation design and poor building materials (Fatoba et al., 2010). Adagunodo et al, (2017) reported that structural failure is one of the concerns of earth scientists in the recent time and stated that most of the building engineers neglect investigation into the subsurface structure prior to construction without taking into cognizance the soil type and its variation which is one of the contributing factors to frequent building collapse in this era. In addition, investigation into structural failures are therefore not only expected to identify trends leading to structural foundation failure but are also expected to suggest solution(s) against the trends as reported by Sunmonu et al., (2013). Furthermore, Adagunodo et al., (2015) reveal that the importance of subsurface structural stability and competency of a building cannot be over emphasized due to the fact when building fails; it's usually goes with loss of lives and properties. Therefore, according to Telford et al, (1976), geophysical method of subsurface investigation provides a relatively rapid and cost effective means of deriving large area information coverage of subsurface geology. Sunmonu et al., (2013; 2018), reported that geophysical methods and analysis are routinely used for investigating structural competency since this approach has been found as the only remedy for this ugly incidence because this approach will map the subsurface variation experienced in order to predict the nature of the proposed site for construction. Consequently, soil physical properties are important factors while evaluating the rate of stability and competency within the soil. According to Walter (2015), soil type is considered as an important factor in structural competency due to the fact that the study of soil physical properties such as textural classification, particle size distribution (soil texture), bulk density, porosity, moisture content, and permeability is 
essential because these are parameters that affect the movement of subsurface competency. In view of the above, the present study utilized Vertical Electrical Sounding (VES) techniques and microstudy of soil properties to investigate into an abandoned dumpsite for Assessment of Subsurface Structural stability and competency within Bowen University, Iwo, Nigeria. Therefore, the objective of the present study is to utilise geophysical characterization of an abandoned dumpsite soil properties for pre-foundation delineation at the Bowen University Campus, Iwo, Nigeria.

\section{MATERIALS AND METHODS}

Bowen University, Iwo southwestern Nigeria is located within a coordinate of between latitude $7^{\circ} 50^{\prime}$ to $8^{\circ} 00^{\prime} \mathrm{N}$ and longitude $4^{\circ} 00^{\prime}$ to $5^{\circ} 00^{\prime} \mathrm{E}$.

The landscape consists of old hard rocks and the area is covered by Precambrian igneous and metamorphic rocks which extend over the area and lies in the Precambrian basement complex of southwestern Nigeria. Locally, Migmatite are found in the study area and its environs (Fig. 1).

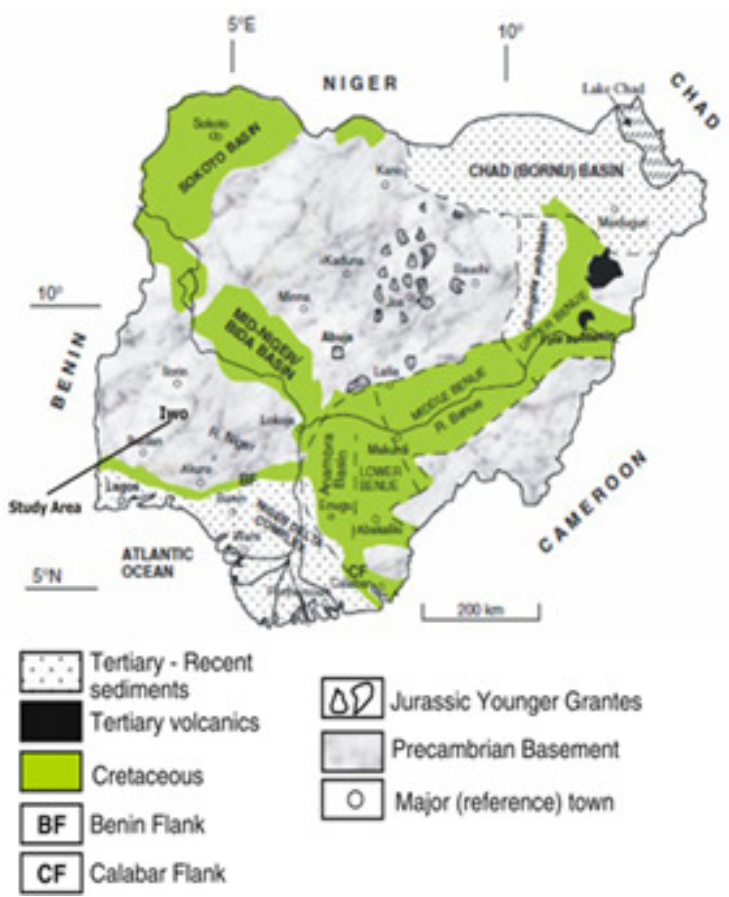

Fig 1: Map of Nigeria showing the Geology of the study area

The study was aimed at understanding the thickness of the dumpsite and competency of the bedrock in the subsurface. This was done in order to recommend whether the study area is competent enough for the construction of building structure or not due to the fact that high-rise building that is constructed on an unstable superficial soil formation might experience differential settling of buildings which might result to related failure in near or far future. The study area is located within the tropical climate, marked by the alternating wet and dry seasons. Temperature is moderately high during the day and also varies from season to season. This resulted into two periods of high temperature as recorded annually (Akinloye et al., 2002). The first period occurs in March-April and the second period in November-December. The average dial temperature varies between $20{ }^{\circ} \mathrm{C}$ for a very cold day and about $35^{\circ} \mathrm{C}$ for a very hot day. The coolest period is between the middle of the raining season (July-August). The wet season starts in April and ends in early October while the dry season starts in late October and ends in early April. The average amount of rainfall which lies between $1016 \mathrm{~mm}$ and $1524 \mathrm{~mm}$, spread over the period of the wet season. During the dry season, dry dust-laden wind originating from the Sahara desert is experienced (Akinloye et al, 2002).

A geophysical survey was carried out using electrical resistivity method (ERM) employing the Schlumberger electrical array (Zohdy et al., 1974), where four (4) vertical electrical sounding (VES) stations were transversed in the area along north-west direction as shown in (Fig 2). The electrical method was established with maximum half current electrode spacing $(A B / 2)$ varying from $45 \mathrm{~m}$ to $65 \mathrm{~m}$ depending on the spread allowance and depth to basement. Geoelectrical sounding data was interpreted automatedly using WinGLink software version 1.62.08 (WinGLink software, 2008), where the theoretical and auxiliary curves (Keller and Frishchnecht, 1966; Koefoed, 1979) were curve matched in order to obtain the resistivity values of different subsurface layers and their corresponding thicknesses and electrical resistivity of each layers. In order to have an output results with low roof mean square (RMS) values, the geoelectrical parameters obtained from WinGLink were further refined using a forward modeling computer algorithm, WinResist version 1.0 software (Vander Velpen, 2004).

However, the microstudy of the soil properties was carried out by determining the bulk density, particle density and the porosity. Soil sample were collected from three selected points located at the entrance, centre and the end of the dumpsite as shown in (Fig 2), at about a depth $0-60 \mathrm{~cm}$ using a core sampler attached to a soil auger. Control sample was taken at location about 200 meters from the dumpsite. The core sampler with soil was firmly tied in a sample bag and labelled for laboratory analysis. 

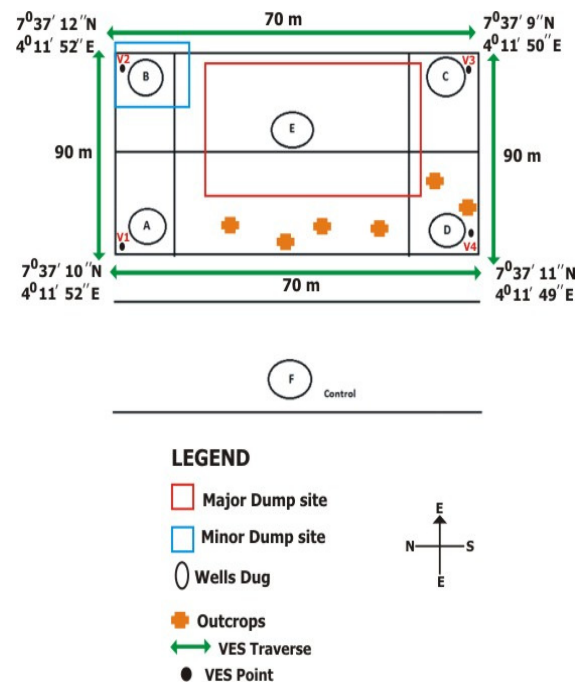

Fig 2: Showing the Base Map of the Study Area

Electrical Resistivity Method: The foundation of electrical resistivity theory is Ohm's, which states that the current flowing through a metallic conductor is directly proportional to the potential difference between its terminal ends provided that temperature and other physical conditions are kept constant.

Mathematically;

$$
V=I R
$$

$\mathrm{V}=$ potential difference, measured in volts $(\mathrm{V}) ; \mathrm{I}=$ current, measured in ampere (A); $\mathrm{R}=$ constant known as resistance, measured in ohms $(\Omega)$

From the current (I) and voltage (V) values, an apparent resistivity $(\rho a)$ value is calculated i.e. $\rho a=$ $k \frac{V}{I}$, where $\mathrm{k}$ is the geometric factor which depends on the arrangement of the four electrodes. Resistivity meters normally give a resistance value $R=\frac{V}{I}$, so in practice the apparent resistivity value is calculated by $\rho_{a}=\mathrm{k} \mathrm{R}$

Microstudy of Soil Properties: Bulk Density, Db formula: Bulk density values represent the density of the oven dry soil as a whole; this includes solids and pore space.

$$
D b=\frac{W s}{V t}
$$

$\mathrm{Ws}=$ Oven dry mass of the sample $(\mathrm{g}): \mathrm{Vt}=$ Total volume of the sample, pore volume + solid volume $\left(\mathrm{cm}^{3}\right)$.

Particle Density, Dp formula: Particle density values represent only the weight of dry soil per unit volume of the soil solids; the pore space is not included in the volume measurement.

Determination of Porosity: Porosity or void fraction of soil is a measure of the void (i.e. "empty") spaces in soil, and is a fraction of the volume of voids over the total volume, between 0 and 1 , or as a percentage between 0 and $100 \%$ and shown mathematically by equation. The porosity of the soil is related to the soil bulk density and soil particle density as shown in equation.

$P S=\frac{v p}{v t}$

$P S=1-\frac{D b}{D p}$

$\mathrm{Vp}=$ Volume of the pores: $\mathrm{Vt}=$ Total volume of the sample, pore volume + solid volume $\left(\mathrm{cm}^{3}\right)$; Note: Vp is difficult to measure, so it is more common to calculate PS from Db and Dp.

\section{RESULT AND DISCUSSION}

Vertical Electrical Sounding (VES) interpretation: The VES results are presented as the resist graph/VES curves (Fig. 3a to 3d). The VES curves were modelled from the computer and made sure that the RMS-error is as low as possible. It was observed that all the VES showed four earth layer models. The overburden thickness of the study area varied from 1.3 to $15.4 \mathrm{~m}$ which showed that the study area is underlain with thick overburden and with resistivity ranges from about 357.4 to 6311.6 ohms. The overburden where revealed at VES 1 between 14 to $18 \mathrm{~m}$ deep, VES 2 is between 10 to $15 \mathrm{~m}$ deep, VES 3 is between 10 to $15 \mathrm{~m}$ deep and VES 4 is between 10 to $15 \mathrm{~m}$ deep and the fracture zones occurred at 30 $\mathrm{m}$ at VES 1 and VES 2 respectively but it was revealed at 15 to $35 \mathrm{~m}$ deep at VES 4.. The classification of the sounding curves showed that all the VES are H-curve type respectively in the study area.

The four iteration for the VES stations were grouped into six profiles according to how convenient they can be located on a straight line to see image representation of the subsurface. The results of the interpreted resist graph/VES curves were used to draw 2D geoelectric sections (Fig. 4a to 4f) along profiles $\mathrm{A}$ and $\mathrm{B}$ to show the vertical distribution of subsurface resistivity within the volume of the earth in the investigated area. 


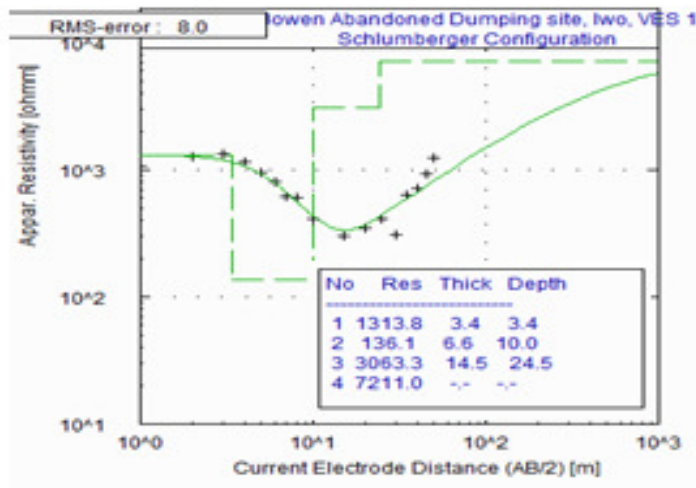

Fig 3a: Resist graph showing iteration for VES 1

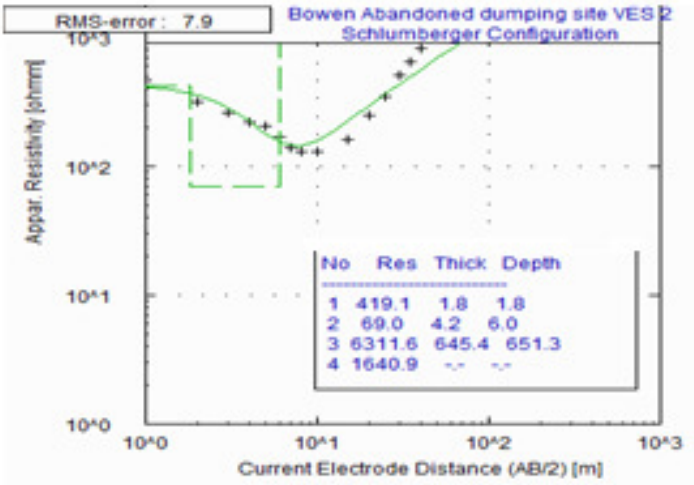

Fig 3b: Resist graph showing iteration for VES 2

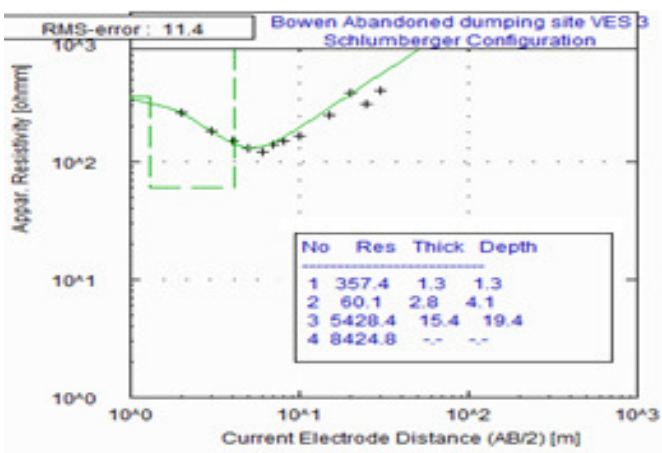

Fig 3c: Resist graph showing iteration for VES 3

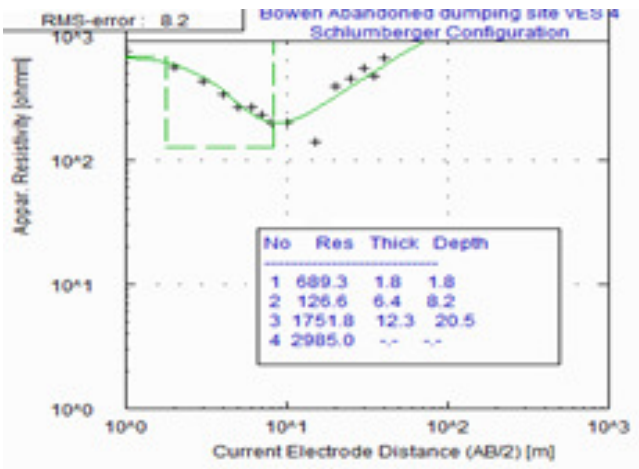

Fig 3d: Resist graph showing iteration for VES 4
The section consists sequence of uniform horizontal (or slightly inclined) layers (horizons). Each layer (horizons) in a geo-electrical section may completely be characterized by its thickness and true resistivity. The geoelectric sections show subsurface variation in electrical resistivity along the profiles and attempt to correlate the geoelectric sequence across the profiles.

In the first layer, the resistivity values ranged from 357.4 to $1313.8 \Omega \mathrm{m}$ with a relative thickness of 1.8 to $3.4 \mathrm{~m}$. The second layer has resistivity values varying from 60.1 to $136.1 \Omega \mathrm{m}$ with relative thickness of 2.8 to $6.6 \mathrm{~m}$. However, the low resistivity values depicted in these layers is due to pollution which resulted from the high porosity and permeability characteristics of the sandy soil encouraging the seepages of the leachate plumes to a maximum depth of $24.5 \mathrm{~m}$ at the subsurface but extreme at VES 3 to maximum depth of $651.3 \mathrm{~m}$. The region of this layer beneath VES 2 conducted on the waste disposal site where there is older wastes deposit depicted low resistivity value of $60.1 \Omega \mathrm{m}$.

It also reveals an elevation in the resistivity values in the order VES 1, 3, and 4 which revealed that the leachate emanated from the region where there is older deposit of wastes and spreading out in all direction polluting the subsurface nearby in the process. This geoelectric layer also served as the first investigation on the research site. The third layer has resistivity values varying from 1751.8 to $6311.6 \Omega \mathrm{m}$ with relative thickness of 12.3 to extreme depth of $645.4 \mathrm{~m}$, which indicated the presence of fresh basement. The thickness of this geoelectric layer is to an infinite depth.

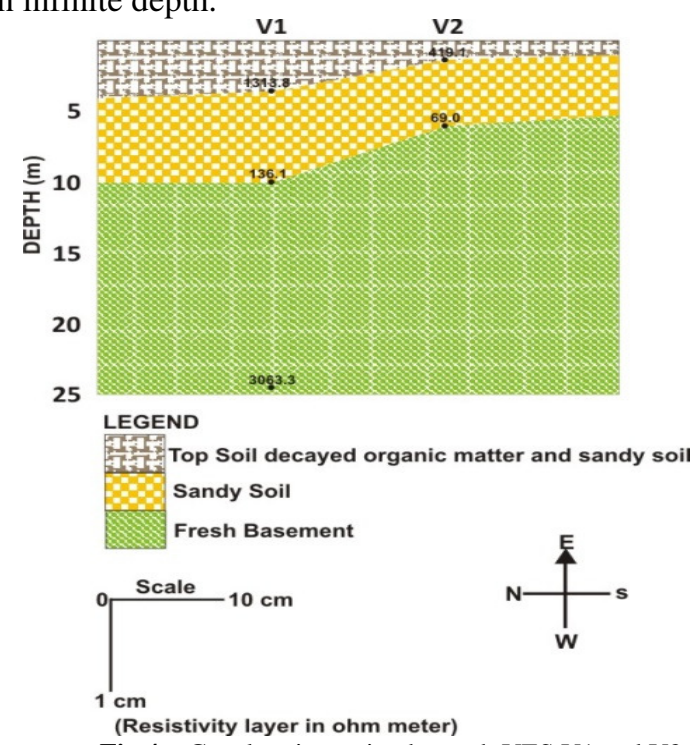

Fig 4a: Geoelectric section beneath VES V1 and V2 


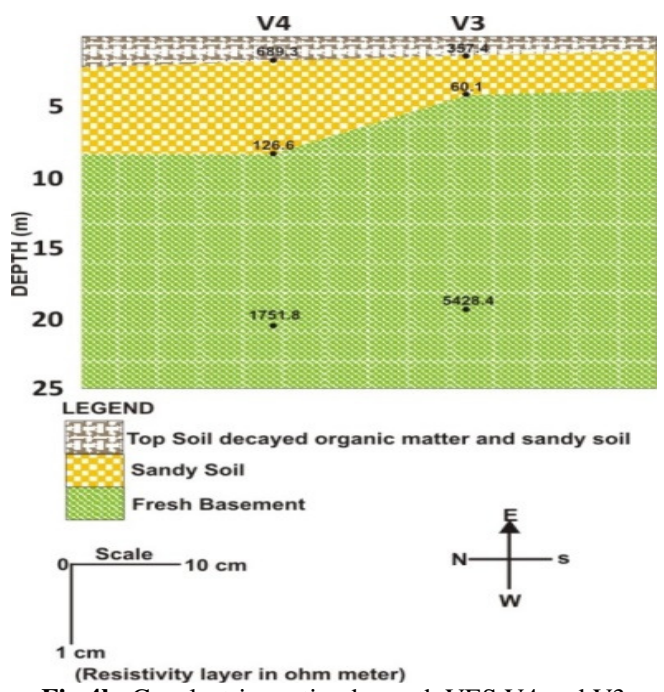

Fig 4b: Geoelectric section beneath VES V4 and V3

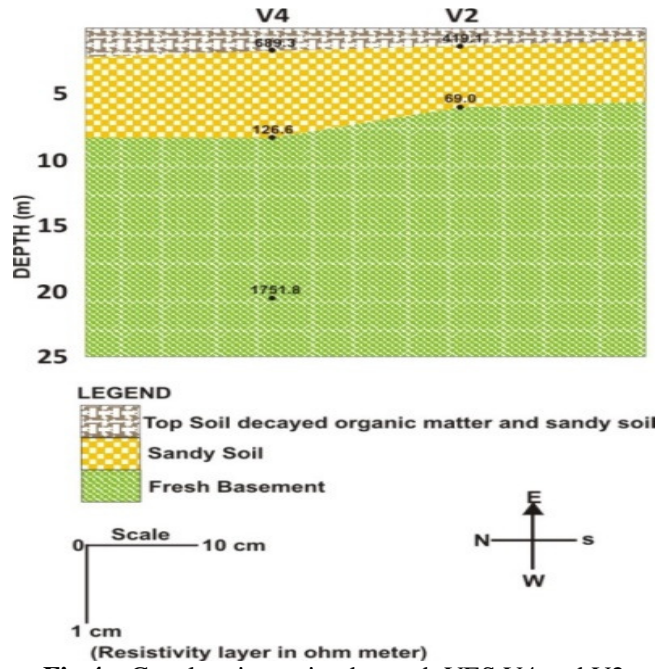

Fig 4c: Geoelectric section beneath VES V4 and V2

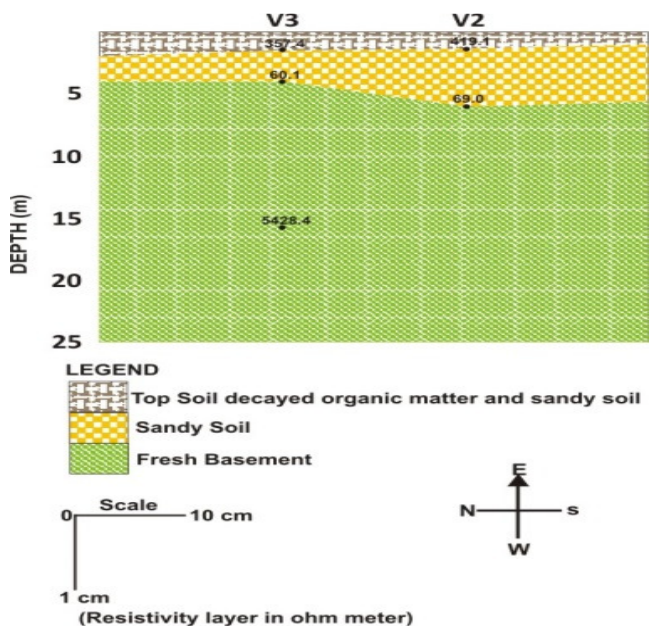

Fig 4d: Geoelectric section beneath VES V3 and V2
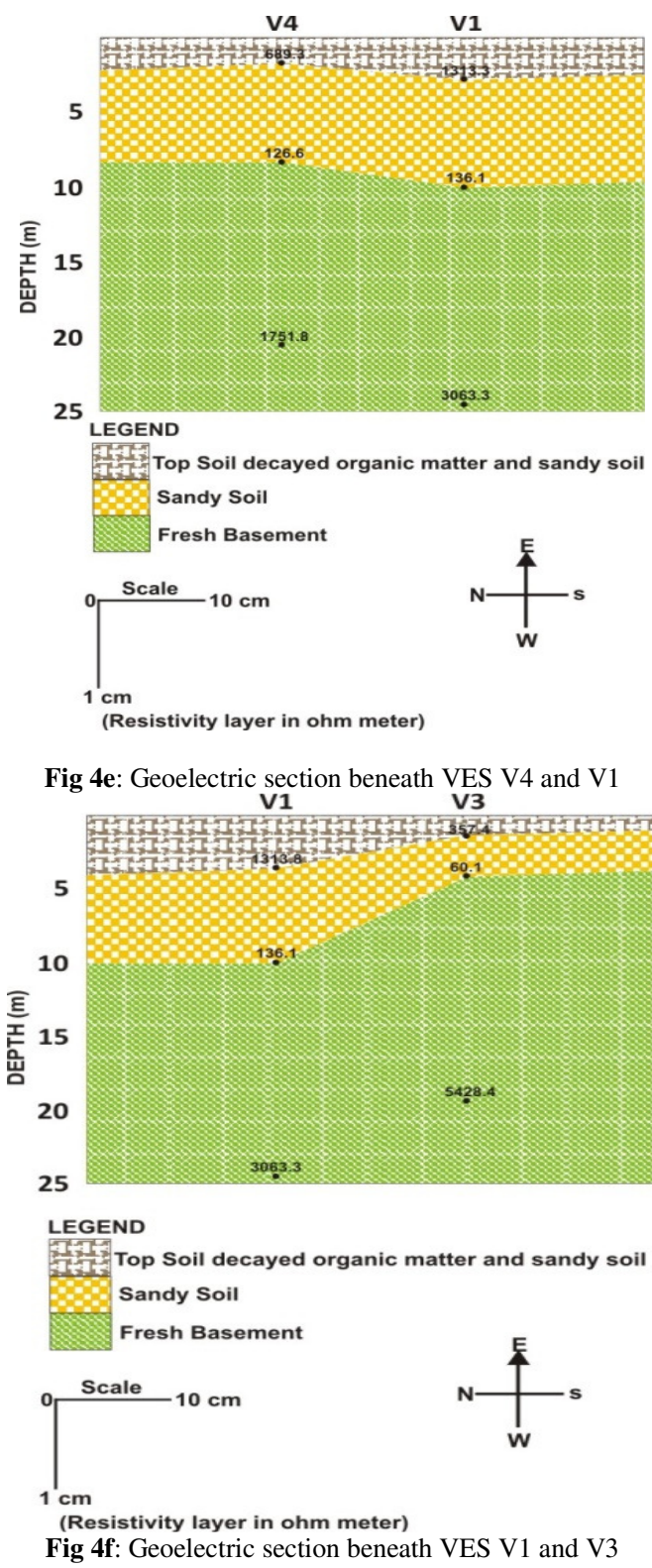

Soil Properties Determination: Effect of Dumpsites on Bulk Density: The Control dumpsite recorded the highest bulk density of $1.45 \mathrm{gcm}^{-3}$ and this observed bulk density was higher than that of the other samples within the dumpsites (Table 1). In addition, this is in line with the study of Njoku, et al., (2015); Okonkwo, et al., (2013), they both observed higher bulk density at the outside dumpsite i.e. the Controlled than any well within the dumpsite in their study on the effects of wastes on Selected Soil Properties in Abakaliki Southeastern Nigeria and that of changes in physical and chemical properties of soil in a timber saw mill dumpsite in Abakaliki, Southeastern Nigeria respectively. Figure 5a shows a bar chart for the average bulk density of various well. 
Table 1: Showing the Bulk density of the various soil samples

\begin{tabular}{lllllll}
\hline Soil & $\begin{array}{l}\text { Mass of } \\
\text { cylinder } \\
(\mathrm{g})\end{array}$ & $\begin{array}{l}\text { Cylind } \\
\text { er }+ \\
\text { soil }(\mathrm{g})\end{array}$ & $\begin{array}{l}\text { Mass } \\
\text { of soil } \\
(\mathrm{g})\end{array}$ & $\begin{array}{l}\text { Volume of } \\
\text { uncompacted } \\
\text { soil }\left(\mathrm{cm}^{3}\right)\end{array}$ & $\begin{array}{l}\text { Bulk density of } \\
\text { uncompacted } \\
\text { soil }\left(\mathrm{g} / \mathrm{cm}^{3}\right)\end{array}$ & $\begin{array}{l}\text { Avg bulk density } \\
\text { of uncompacted } \\
\text { soil }\left(\mathrm{g} / \mathrm{cm}^{3}\right)\end{array}$ \\
\hline Control & 148 & 432 & 284 & 200 & 1.42 & \\
Control & 151 & 461 & 310 & 200 & 1.55 & 1.45 \\
Control & 148 & 424 & 276 & 200 & 1.38 & \\
Well A & 148 & 458 & 310 & 200 & 1.55 & 1.41 \\
Well A & 149 & 425 & 276 & 200 & 1.38 & \\
Well A & 151 & 413 & 262 & 200 & 1.31 & \\
Well B & 148 & 394 & 246 & 200 & 1.23 & \\
Well B & 148 & 422 & 274 & 200 & 1.37 & \\
Well B & 151 & 424 & 273 & 200 & 1.37 & \\
Well C & 148 & 455 & 307 & 200 & 1.54 & \\
Well C & 149 & 480 & 331 & 200 & 1.66 & \\
Well C & 151 & 356 & 205 & 200 & 1.03 & \\
Well D & 148 & 391 & 243 & 200 & 1.22 & \\
Well D & 149 & 432 & 283 & 200 & 1.42 & \\
Well D & 151 & 380 & 229 & 200 & 1.15 & \\
Well E & 148 & 455 & 307 & 200 & 1.54 & \\
Well E & 149 & 447 & 298 & 200 & 1.49 & \\
Well E & 151 & 361 & 210 & 200 & 1.05 & \\
\hline
\end{tabular}

Effect of dumpsites on particle density: The weight per unit volume of the solid portion of soil is called particle density. Table 2 shows the result for the particle density of soil within the study area. A typical value of $2.65 \mathrm{~g} / \mathrm{cm}^{3}$ has been suggested to characterize the soil particle density of a general mineral soil (Freeze and Cherry 1979). The particle density is higher if large amount of heavy minerals such as magnetite; limonite and hematite are present in the soil.. In addition, Fig. 5b shows a bar chart for the average particle density of well.

\begin{tabular}{llllll}
\multicolumn{7}{c}{ Table 2: Showing the result for the particle density of soil } \\
\hline Soil & $\begin{array}{l}\text { Volume of } \\
\text { water }\left(\mathrm{cm}^{3}\right)\end{array}$ & $\begin{array}{l}\text { Mass of } \\
\text { soil }(\mathrm{g})\end{array}$ & $\begin{array}{l}\text { volume of water }+ \\
\text { soil }\left(\mathrm{cm}^{3}\right)\end{array}$ & $\begin{array}{l}\text { Difference } \\
\left(\mathrm{cm}^{3}\right)\end{array}$ & $\begin{array}{l}\text { Particle density } \\
\left(\mathrm{g} / \mathrm{cm}^{3}\right)\end{array}$ \\
\hline Control & 100 & 100 & 138 & 38 & 2.63 \\
Control & 100 & 100 & 138 & 38 & 2.63 \\
Control & 100 & 100 & 138 & 38 & 2.63 \\
Well A & 100 & 100 & 135 & 35 & 2.86 \\
Well A & 100 & 100 & 136 & 36 & 2.78 \\
Well A & 100 & 100 & 136 & 36 & 2.78 \\
Well B & 100 & 100 & 134 & 34 & 2.94 \\
Well B & 100 & 100 & 134 & 34 & 2.94 \\
Well B & 100 & 100 & 134 & 34 & 2.94 \\
Well C & 100 & 100 & 135 & 35 & 2.86 \\
Well C & 100 & 100 & 134 & 34 & 2.94 \\
Well C & 100 & 100 & 135 & 35 & 2.86 \\
Well D & 100 & 100 & 134 & 34 & 2.94 \\
Well D & 100 & 100 & 134 & 34 & 2.94 \\
Well D & 100 & 100 & 134 & 34 & 2.94 \\
Well E & 100 & 100 & 132 & 32 & 3.13 \\
Well E & 100 & 100 & 131 & 31 & 3.23 \\
Well E & 100 & 100 & 132 & 32 & 3.13 \\
\hline
\end{tabular}

Effect of dumpsite on porosity: Porosity or pore space is the amount of air space or void space between soil particles. It also refers to the volume of soil voids that can be filled by water and/or air. The porosity or percentage pore space is calculated from the particle density and bulk density.

From Table 3, which shows the result of calculated porosity and average porosity of the soil samples, the order of increase in the average total porosity is WELL D, WELL E, WELL B, WELL C, WELL A with average period 57.22\%, 57.03\%, 55.06\%, $51.38 \%, 49.64 \%$ respectively.

The control has the lowest average total porosity of $44.90 \%$. The differences in soil total porosity may be due to differences in organic matter content of the sites. This is because higher organic matter helps to build soil aggregates and increasing pore space. (Brevik, E.C, 2009). 


\begin{tabular}{cllll} 
Table 3: Showing the result of calculated porosity and average porosity of the soil samples \\
\hline Soil & $\begin{array}{l}\text { Bulk density of } \\
\text { uncompacted } \\
\text { soil }(\mathrm{g} / \mathrm{cm} 3)\end{array}$ & $\begin{array}{l}\text { Particle } \\
\text { density } \\
\text { of soil }(\mathrm{g} / \mathrm{cm} 3)\end{array}$ & $\begin{array}{l}\text { Porosity of } \\
\text { uncompacted } \\
\text { soil }(\%)\end{array}$ & $\begin{array}{l}\text { Avg porosity of } \\
\text { uncompacted } \\
\text { soil }\end{array}$ \\
\hline Control & 1.42 & 2.63 & 46.04 & \\
Control & 1.55 & 2.63 & 41.10 & 44.90 \\
Control & 1.38 & 2.63 & 47.56 & \\
Well A & 1.55 & 2.86 & 45.75 & \\
Well A & 1.38 & 2.78 & 50.32 & 49.64 \\
Well A & 1.31 & 2.78 & 52.84 & \\
Well B & 1.23 & 2.94 & 58.18 & \\
Well B & 1.37 & 2.94 & 53.42 & 55.06 \\
Well B & 1.37 & 2.94 & 53.59 & \\
Well C & 1.54 & 2.86 & 46.28 & \\
Well C & 1.66 & 2.94 & 43.73 & 51.38 \\
Well C & 1.03 & 2.86 & 64.13 & \\
Well D & 1.22 & 2.94 & 58.69 & \\
Well D & 1.42 & 2.94 & 51.89 & 57.22 \\
Well D & 1.15 & 2.94 & 61.07 & \\
Well E & 1.54 & 3.13 & 50.88 & \\
Well E & 1.49 & 3.23 & 53.81 & 57.03 \\
Well E & 1.05 & 3.13 & 66.40 & \\
\hline
\end{tabular}

The control well has the highest average density with Well $\mathrm{A}$ and Well $\mathrm{C}$ having the same average bulk density this can be explains by the base map. It was seen that Well A and C are located at the edge of the dumpsite as opposed to Well D and E which location happen to in the middle of dumpsites.

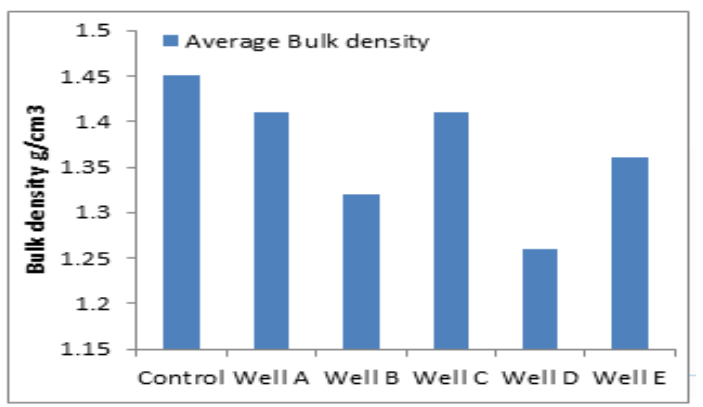

Fig 5a: Average Bulk density

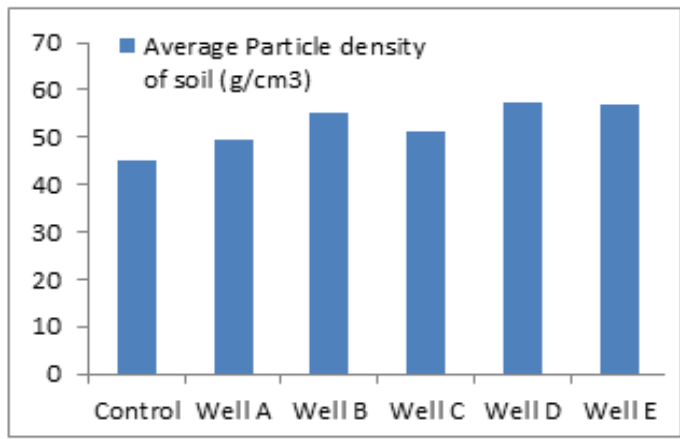

Fig 5b: Average particle density
From Table 2, it noticed that the particle density of the samples taken from the Control well is lesser than that of the other wells which is almost close to suggested particle density of mineral soil. The highest particle density is discovered in Well $\mathrm{E}$ has shown in Fig $5 \mathrm{~b}$. The reason for the high particle density in the Well E, D, B, C, A is because of the presence of heavy metals that limits the activities of soil organism and WELL $\mathrm{E}$ has the highest because it is located at the centre of the dumpsite where most burning activities takes places.

Conclusion: From the correlation of the VES interpretation and the microstudy of the soil properties, it was discovered that the overburden is not competent to withstand high rise building or some special designed low - rise building in the study area. Therefore, artificial basement should be probably be considered, designed and approved so as to help the foundation to withstand any dynamic movement of the subsurface to any related structural failure such as cracks, or eventual collapse that may occur in near or far future, which may lead to loss of lives and properties.

\section{REFERENCES}

ADAGUNODO, TA. ADENIJI, AA. ERINLE, AV. AKINWUMI, SA. ADEWOYIN, OO. JOEL, ES. KAYODE, OT. (2017). Geophysical investigation into the integrity of a reclaimed open dumsite for 
civil engineering purpose. Interciencia Journal 42(11): $324-339$.

ADAGUNODO, TA. SUNMONU, LA. ADENIJI, AA. (2015b). Effect of Dynamic Pattern of the Saprolitic Zone and its Basement on Building Stability: a Case Study of a High-Rise Building in Ogbomoso. Journal of Applied Physical Science International 3(3): 106-115.

AKINLOYE, MK. FADIPE, DO. ADABANIJA, MA. (2002). A Radiometricmapping of the Ladoke Akintola University Compus, Ogbomoso Southwestern Nigeria. Science Focus 1: 55-61

BREVIK, EC. CERDA, A. MATAIX-SOLERA, J. PEREG, L. QUINTON, JN. SIX J. CAN OOST, K. (2015). The interdisciplinary nature of soil. (1): 117 - 129 .

FATOBA, JO. ALO, JO. FAKEYE, AA. (2010). Geoelectric imaging for foundation failure investigation at Olabisi Onabanjo University mini campus, Ago Iwoye, Southwestern Nigeria. Journal of Applied Sciences Research 6(12): 2192-2198

KELLER, S. FRISCHNECHT, N. (1970). An interactive computer/graphic-display-terminal system for interpretation of resistivity soundings. Geophysics Prospect. 23, 449-458.

KOEFOED, O. (1979). Geosounding Principles, 1: Resistivity Sounding measurements. Elsevier Scientific Publishing Comp., Amsterdam. 275.

SUNMONU, LA. ADAGUNODO, TA. ADENIJI, AA. AJANI, OO. (2018). Geoimaging of subsurface fabric in Awgbagba, Southwestern Nigeria using geomagnetic and geoelectrical techniques. Malaysian Journal of Fundamental and Applied Sciences 14(2): 312-324

NJOKU, C. OKORO, GC. (2015). Effect of flooding on soil properties in Abakaliki Eastern Nigeria. Scholarly Journal of Agricultural Science. 5(5): $165-168$.

OKONKWO, CL. ARINZECHUWU, P. NJOKU C. (2013). Changes in Physical and Chemical Properties of Soil in Timber Saw Mill Dumpsite. British Journal of Environmental and Climate Changes 3(2): 215 - 228

SUNMONU LA. ALAGBE OA. MABUNMI, SA. ADENIJI, AA. OLASUNKANMI, NK. (2013). Geophysical Investigation into the Cause(s) of Structural Failure within BACOSA and Faculty of Science Buildings, Bowen University Temporary Site, Iwo. Advances in Physics Theories and Applications. 25, 1-17.

TELFORD, WM. GELDART, LP. SHERIFF, RE. (1976). Applied Geophysics (2nd Ed.) Cambridge: Cambridge University Press

VANDER-VELPEN BPA. (2004). WinResist Version 1.0. Resistivity Sounding Interpretation Software. M.Sc. Research Project, ITC, Delft Netherland.

WALTER, E. (2015). Why buildings collapse in Nigeria. Unite Nigeria, 1.

WINGLINK-SOFTWARE. (2008). Version 1.62.08 - 20030519. January 10. Geosystem SRL. Via Clericetti 42a, 20133 Milan, Italy

ZOHDY, AA. MABOY, DR. (1974). Application of surface geophysics to groundwater investigation. U.S. Geol. Surv. Book 2 Ch. D1, 304-320. 